\title{
Need Analysis for the Development of Learning Video Based on Explaindio in Physics Lesson of Senior High School to Improve Learning Outcomes During the Covid-19 Pandemic
}

\author{
Nurliana $^{1,2}$, Zulirfan ${ }^{2}$, Fakhruddin $^{2}$ \\ ${ }^{1}$ SMAN 4 Pekanbaru, 28125, Indonesia \\ ${ }^{2}$ Master of Physics Education, Riau University, Pekanbaru, 28293, Indonesia
}

\section{ARTICLE INFO}

\section{Article history:}

Received: 31 Dec 2020

Revised: 16 June 2021

Accepted: 20 June 2021

Published online: 24 July 2021

\section{Keywords:}

Need Analysis

Explaindio

Learning Outcomes

Learning Videos

\begin{abstract}
A B S T R A C T
During the Covid-19 pandemic, learning is no longer undertaken offline (outside the network) but online (in the network). This condition demands the informative and communicative media for learning activities. One of the media that can be directly interacting with students is learning video. The teacher needs to conduct a needs analysis to ensure the use of learning videos, especially those based on Explaindio. The research was conducted in a correlational quantitative approach. The action research was undertaken at SMA Negeri 4 Pekanbaru with a sample of 36 students. The data collected from the questionnaire consisted of 10 items. Data analysis by substituting respondents' results through descriptive statistics, Product Moment correlation, and t-test. The results of the analysis indicated that the importance of utilizing meaningful videos to meet the learning needs of students. Learning videos based on Explaindio provide space for teachers to design videos in accordance with their needs. Complete and communicative learning videos can provide meaningful information and experiences to students so that they have a positive impact on student learning progress.
\end{abstract}

\section{Introduction}

Learning is a complex process. In its implementation, the various facilities and infrastructure are needed to support the success of learning outcomes. One of these facilities is learning media. Learning media is a means that is able to facilitate teachers and students during the process of teaching and learning activities that have been undertaken. Several existing studies indicate that learning media can be useful if it is used appropriately by teachers when the implementation of learning begins with accuracy in planning, using, and evaluating and the right media can certainly present good learning outcomes

\footnotetext{
* Corresponding author.

E-mail: nurliana201506@gmail.com
}

Doi: https://doi.org/10.31258/jes.5.3.p.491-501 
(Budiyono, 2020; Ekayani, 2017). At the point of this success, the media used as a learning tool must be ensured that the media can be used proficiently by the teacher (Falahudin, 2014).

During the Covid-19 pandemic, learning is no longer undertaken offline (outside the network) but online (in the network) (Zulhafizh, 2020a; Zulhafizh \& Permatasari, 2020). This condition demands teachers to think about media that can be used in learning activities. The selected media definitely can facilitate all student learning activities during face-to-face learning activities cannot be implemented. One of the media that can be directly interacting with students is learning video. Students can indirectly interact with the teacher. However, the concept of this video is one way.

The existence of a video enables students to notice the teacher's explanation. Students can measure the speed and slowness of existing explanations, so then it is easier to understand the material or explanation presented. On the other hand, the existence of learning videos has assisted students to repeat explanations when they forget or hesitate (Salmina, 2019; Al-Tabany, 2017). Learning videos that meet learning content standards are certainly very helpful for students in learning (Hamdanillah, Harjono, \& Susilawati, 2017). In accordance with this explanation, a teacher needs to conduct a review of the things that need to be done for the manufacture or development of learning media.

A review of the development of learning videos as an initial step before the design is technically undertaken. A teacher can ask students directly or indirectly what they want if a teacher provides a learning video. This learning video is a real teacher representative. Thus, it is in line with this explanation, this article seeks to analyze the need for developing explaindio-based learning videos, especially in physics subjects. The analysis of the need for developing the learning video is an important note for teachers (Ichsan et al, 2018) to create the design. The appropriate design can certainly help and maximize learning activities.

Explaindio itself is a device that can assist teachers in presenting learning videos. This device is easy and interesting to learn. Explaindio has the advantage to be used in presentation activities, promotions, animations, and so on. With these advantages, Explaindio can be used for learning activities, such as: providing learning with an attractive design and appearance, providing learning motivation, it facilitates to create of various illustrations so that learning objectives are directed and can be achieved properly.

In line with its advantages, the use of learning videos based on Explaindio is expected to encourage and motivate students in learning. Motivation can encourage students to act (as movers) and direct students to achieve learning goals (Putri \& Isnani, 2015) so that if students have acted as movers or are motivated in learning, they definitely can increase their learning motivation and improve learning outcomes, especially during this Covid-19 pandemic. The development of learning media such as learning videos is an important part to direct students' 
enthusiasm for learning. Creative use of explaindio is able to present designs and illustrations that can strengthen knowledge and learning experiences.

\section{Methodology}

The research was undertaken with a correlational quantitative approach. The study was conducted at SMA Negeri 4 Pekanbaru with a sample of 36 students. Each consisted of 14 men and 22 women. The data used to collect data is in the form of a questionnaire with open ended questions. The results of the analysis of validity and reliability, all data were valid with Cronbach's Alpha 0.746. The questionnaire used was 10 items. The process of data collection by utilizing google forms. Data analysis was undertaken by substituting respondents' results through descriptive statistics, followed by correlation analysis through Product Moment correlation and then t-test. The correlative decision used a significance level between +1.00 and -1.00 refer to Zulhafizh (2020) as in Table 1.

Table 1. Interpretation of Significance Level

\begin{tabular}{ccc}
\hline No. & Scale & Category \\
\hline 1 & 1 & Perfect \\
2 & 0,75 until 0,99 or $-0,75$ until $-0,99$ & Very Strong \\
3 & 0,50 until 0,75 or $-0,50$ until $-0,75$ & Strong \\
4 & 0,25 until 0,50 or $-0,25$ until $-0,50$ & Enough \\
5 & 0,0 until 0,25 or $-0,0$ until $-0,25$ & Weak \\
6 & 0,00 & No Correlation \\
\hline
\end{tabular}

\section{Results and Discussion}

\section{Finding and Discussion}

\section{Demographics}

Demographic data from research results can be mapped based on gender, namely male and female. The data can be seen in table 2 .

Table 2. Demographic Distribution Based on Gender

\begin{tabular}{ccc}
\hline Group & N & Percentage \\
\hline Male & 14 & 38,89 \\
Female & 22 & 61,11 \\
Total & 36 & 100 \\
\hline
\end{tabular}

Table 2 can be seen that male respondents consist of 14 people with a percentage of $38.89 \%$ and female respondents consist of 22 with a percentage of $61.11 \%$. This implies that there are more female respondents. There are 36 people in total. Each respondent has characteristics in responding to the data analysis, especially if it is associated with gender. 


\section{Descriptive Data}

Research data consists of 10 questions. Each question has several alternative answers that vary. This has been adjusted to the pattern or form of the question. The data can be seen in table 3 .

Table 3. Descriptive Results of Respondents

\begin{tabular}{|c|c|c|c|c|}
\hline No. & Indicator & $\begin{array}{l}\text { Observation } \\
\text { Information }\end{array}$ & $\mathbf{N}$ & Percentage \\
\hline \multirow[t]{5}{*}{1} & \multirow{5}{*}{$\begin{array}{l}\text { How many times doe students look at } \\
\text { the clock during the learning activity? } \\
\text { (P1) }\end{array}$} & $1-2$ times & 9 & 25,00 \\
\hline & & 3-4 times & 19 & 52,78 \\
\hline & & 5-6 times & 4 & 11,11 \\
\hline & & $7-8$ times & 1 & 2,78 \\
\hline & & 9-10 times & 3 & 8,33 \\
\hline \multirow[t]{5}{*}{2} & \multirow{5}{*}{$\begin{array}{l}\text { How many times do you leave vicon } \\
\text { (Video Conference) during teaching } \\
\text { and learning activity? (P2) }\end{array}$} & 1-2 times & 22 & 61,11 \\
\hline & & 3-4 times & 8 & 22,22 \\
\hline & & 5-6 times & 0 & 0 \\
\hline & & $7-8$ times & 4 & 11,11 \\
\hline & & 9-10 times & 2 & 5,56 \\
\hline \multirow[t]{4}{*}{3} & \multirow{4}{*}{$\begin{array}{l}\text { Are you happy of learning through } \\
\text { learning video sent by the teacher? } \\
\text { (P3) }\end{array}$} & Happy & 8 & 22,22 \\
\hline & & Less Happy & 9 & 25,00 \\
\hline & & Happy Enough & 18 & 50,00 \\
\hline & & Unhappy & 1 & 2,78 \\
\hline \multirow[t]{2}{*}{4} & \multirow{2}{*}{$\begin{array}{l}\text { Are the videos that you ever seen } \\
\text { through youtube/other social media } \\
\text { help your creativity in learning? (P4) }\end{array}$} & Yes & 30 & 83,33 \\
\hline & & No & 6 & 16,67 \\
\hline \multirow[t]{2}{*}{5} & \multirow{2}{*}{$\begin{array}{l}\text { Do they help you in answering the } \\
\text { critical questions? (P5) }\end{array}$} & Yes & 21 & 58,33 \\
\hline & & No & 15 & 41,67 \\
\hline \multirow[t]{2}{*}{6} & \multirow{2}{*}{$\begin{array}{l}\text { Can learning video accelerate the } \\
\text { comprehension quality when studying? } \\
\text { (P6) }\end{array}$} & Yes & 18 & 50,00 \\
\hline & & No & 18 & 50,00 \\
\hline \multirow[t]{3}{*}{7} & \multirow{3}{*}{$\begin{array}{l}\text { Has the information presented in the } \\
\text { video fulfilled the learning purpose? } \\
\text { (P7) }\end{array}$} & Yes & 9 & 25,00 \\
\hline & & Sometimes & 1 & 2,78 \\
\hline & & No & 26 & 72,22 \\
\hline \multirow[t]{3}{*}{8} & \multirow{3}{*}{$\begin{array}{l}\text { Can you acquire the information } \\
\text { presented in the learning video? (P8) }\end{array}$} & Yes & 9 & 25,00 \\
\hline & & Sometimes & 25 & 69,44 \\
\hline & & No & 2 & 5,56 \\
\hline \multirow[t]{3}{*}{9} & \multirow{3}{*}{$\begin{array}{l}\text { Can the information in the learning } \\
\text { video entertain and help explaining the } \\
\text { information? (P9) }\end{array}$} & Yes & 21 & 58,33 \\
\hline & & Sometimes & 14 & 38,89 \\
\hline & & No & 1 & 2,78 \\
\hline \multirow[t]{3}{*}{10} & \multirow{3}{*}{$\begin{array}{l}\text { Can the display of video content attract } \\
\text { your attention to study? (P10) }\end{array}$} & Yes & 16 & 44,44 \\
\hline & & Sometimes & 16 & 44,44 \\
\hline & & No & 4 & 11,11 \\
\hline
\end{tabular}

Table 3 contains ten questions that are the basis for observing the analysis of the need for developing explaindio-based learning videos in Physics subjects to improve learning outcomes during the Covid-19 pandemic. It is known that $25 \%$ of P1 choose 1-2 times, $52.8 \%$ choose 3-4 times, $11.1 \%$ choose 5-6 times, $2.8 \%$ choose 7-8 times, and the last is $8.3 \%$ who choose $9-10$ times. The percentage results have been obtained, there are 19 students who prefer choose 1-2 times with the highest percentage $52.8 \%$ seeing the clock when the learning activity takes 
place; P2 consists of $61.1 \%$ and the students choose $1-2$ times, $22.2 \%$ choose $3-4$ times, $11.1 \%$ choose $5-6$ times, and $5.6 \%$ choose $9-10$ times. The percentage results obtained are $61.1 \%$ with the number of students as many as 22 people who prefer to choose 1-2 times to leave the vicon (video conference) during teaching and learning activities; P3 consists of $22.2 \%$ who choose happy, $50 \%$ choose quite happy, $25 \%$ choose not to be happy, and $2.8 \%$ choose not to be happy. Based on the highest percentage, there are $50 \%$ of students who choose quite happy, 18 people feel happy to learn through learning videos sent by the teacher.

Furthermore, P4 consists of $83.3 \%$ who choose yes and $16.7 \%$ choose no. Thus, $83.3 \%$ of voters with a total of 30 students who have answered learning videos that viewed through youtube/other social media and it can help creativity in learning; In P5, it has been found that $58.3 \%$ choose yes and $41.7 \%$ choose no, it can be concluded that $58.3 \%$ the highest percentage of 21 people have chosen learning videos to help answer critical questions; In P6, there are 50\% with a total of 18 students who answer yes and $50 \%$ with a total of 18 students who answer no. This percentage is balanced, concerning to positive questions, $50 \%$ of students who answer that learning videos can accelerate the quality of understanding while learning; P7 is obtained $25 \%$ and they choose yes, $72.2 \%$ choose sometimes, and $2.8 \%$ choose no. Based on the most answers, $72.2 \%$ with a total of 26 students, it can be concluded that the students assert that sometimes the information presented in the video has fulfilled the learning objectives.

Then, in P8, 25\% choose yes, $69.4 \%$ choose sometimes, and $5.6 \%$ choose no. It can be concluded based on the most answers, namely $69.4 \%$, consists of 25 people and they argue that they could master the information presented in the learning video; P9 obtained $58.3 \%$ chose yes, $38.9 \%$ chose sometimes, and $2.8 \%$ chose no. Based on the highest number of voters, $58.3 \%$ with a total of 21 students answered yes that animation in learning videos can entertain and help explain information; P10 obtained $44.4 \%$ chose yes, $44.4 \%$ chose sometimes, and $11.1 \%$ chose no. It can be concluded that there is a balance in the percentage of yes and no answers. Then the positive question category was chosen with $44.4 \%$ totaling 16 students answering yes that the video display can attract attention to learning. The diversity of answers is part of the perception data felt by respondents related to the analysis of the need for developing learning videos, in this context based on explaindio.

\section{Contribution of Needs Analysis}

Contribution analysis was carried out to see the level of relationship between each question in measuring the level of need for the development of learning videos. The data can be seen in table 4 . 
Table 4. Correlation Distribution

\begin{tabular}{cccccc}
\hline No. & $\begin{array}{c}\text { Observation } \\
\text { Indicator }\end{array}$ & $\boldsymbol{n}$ & Sig. & $\begin{array}{c}\text { Product Moment } \\
\text { Correlation }\end{array}$ & Category \\
\hline 1 & P1 & 36 & 0,000 & $0,563^{* * *}$ & Strong \\
2 & P2 & 36 & 0,000 & $0,703^{* *}$ & Strong \\
3 & P3 & 36 & 0,000 & $0,483^{* *}$ & Strong \\
4 & P4 & 36 & 0,000 & $0,531^{* *}$ & Strong \\
5 & P5 & 36 & 0,000 & $0,587^{* *}$ & Strong \\
6 & P6 & 36 & 0,000 & $0,597^{* *}$ & Strong \\
7 & P7 & 36 & 0,000 & $0,622^{* *}$ & Strong \\
8 & P8 & 36 & 0,000 & $0,548^{* *}$ & Strong \\
9 & P9 & 36 & 0,000 & $0,622^{* *}$ & Strong \\
10 & P10 & 36 & 0,000 & $0,583^{* *}$ & Strong \\
\hline
\end{tabular}

Table 4 shows that all observational variables are correlated with the analysis of the needs for developing instructional videos. Based on the results of the correlation table substitution, it shows that all data are strongly correlated, P1 has a significance of 0.000 with a correlation of $0.563^{* *}$ in the strong category; P2 has a significance of 0.000 with a correlation of $0.703 * *$ in the strong category; P3 has a significance of 0.000 with a correlation of $0.483^{* *}$ in the strong category; P4 has a significance of 0.000 with a correlation of $0.531^{* *}$ in the strong category; P5 has a significance of 0.000 with a correlation of $0.587^{* *}$ in the strong category; P6 has a significance of 0.000 with a correlation of $0.597^{* *}$ in the strong category; P7 has a significance of 0.000 with a correlation of $0.622 * *$ in the strong category; P8 has a significance of 0.000 with a correlation of $0.548^{* *}$ in the strong category; P9 has a significance of 0.000 with a correlation of $0.622 * *$ in the strong category; and P10 has a significance of 0.000 with a correlation of $0.583 * *$ in the strong category. When viewed with the mean approach, the correlation value is 0.582 with a strong category, at a significance level of 0.000 .

\section{Decision Analysis}

After the correlation analysis was carried out, the t-test analysis was continued to ensure that the question data could provide meaningful information for decisions in the development of explaindio-based learning videos, especially in physics learning. The data can be seen in table 5 .

Table 5. t-Test

\begin{tabular}{cccccc}
\hline No. & Observation Indicator & $\boldsymbol{t}$ & $\boldsymbol{d} \boldsymbol{f}$ & Sig. & Mean Difference \\
\hline 1 & P1 & 11,729 & 35 & 0,000 & 2,167 \\
2 & P2 & 9,354 & 35 & 0,000 & 1,667 \\
3 & P3 & 16,243 & 35 & 0,000 & 2,333 \\
4 & P4 & 18,520 & 35 & 0,000 & 1,167 \\
5 & P5 & 17,000 & 35 & 0,000 & 1,417 \\
6 & P6 & 17,748 & 35 & 0,000 & 1,500 \\
7 & P7 & 22,007 & 35 & 0,000 & 1,778 \\
8 & P8 & 20,643 & 35 & 0,000 & 1,806 \\
9 & P9 & 15,337 & 35 & 0,000 & 1,417 \\
10 & P10 & 14,790 & 35 & 0,000 & 1,667 \\
\hline
\end{tabular}


Table 5 shows that all data are acceptable as observations of the analysis of the needs for developing learning videos. The data characterized by a significant level is not more than 0.000 . This means that there is no difference between one data and another. All data have the same position so that the questionnaire and this data are worthy of being used for making a decision.

\section{Distract}

During the Covid-19 pandemic, almost all learning is undertaken online (Zulhafizh, 2020a). Various learning alternatives are carried out so that students can still get information and develop their experience and knowledge. The challenges faced during distance learning include students' attention to the explanations that presented by the teacher. Students who are already bored with the activities they are going through and it contains of unfocused learning activities (Syaparuddin, Meldianus, \& Elihami, 2020; Kadir, 2014). This is an important note for teachers so that students can participate in intensive learning during class hours.

Students who have experienced boredom in learning can be known by looking at the clock. Data analysis shows that all students look at the clock when learning activities take place, even up to 9-10 times. Another behavior shown by students is to leave learning activities (video conference). Almost all students have left learning activities. This behavior is a form of diverting his attention to others. This situation illustrates that students are not concentrating or bored in learning (Lamba et al, 2014). Students whose learning concentration is disturbed or bored can have an impact on their learning achievement or success (Aviana \& Hidayah, 2015). As students, they need to think of alternatives that can encourage students to continue to give maximum attention to learning.

\section{Learn through Learning Videos}

One of the interactive learning media with students is a learning video. The existence of learning videos can bring students to experience and know directly about the various illustrations presented. Students can imitate or imitate what the teacher says. Data analysis shows that only $2.78 \%$ are not happy with learning videos and $97.72 \%$ are happy with learning videos during the covid-19 pandemic, although the level of enjoyment varies. In the research of Melinda, Degeng, \& Kuswandi (2018); Mutia, Adlim, \& Halim (2017); Busyaeri, Udin, \& Zaenudin (2016) show that learning videos can improve learning achievement and attract the attention of students to stay focused on learning.

This encourages educators to present various learning videos that can facilitate students. In order to complement their curiosity and creativity, they also look at various other means such as youtube or social media. Youtube or social media is part of the platform that can be filled with learning videos. Almost $83.33 \%$ of students use this pathway to broaden their horizons. However, videos that created by teachers will certainly be more focused on learning targets and achievements 
(Nurseto, 2011; Tafonao, 2018). The teacher can design the video in accordance with the learning framework that has been designed and planned.

\section{Critical Learning and Comprehension}

Learning through video can help students be critical of the various problems presented. Students can understand the information in detail according to the capacity of the video. A critical attitude in learning is highly expected during the COVID-19 pandemic (Zulhafizh \& Permatasari, 2020). This is due to learning activities are not direct and it demands the independence. Responding to this issue, it is expected that the quality of student learning outcomes will not decrease and can be improved with their respective learning styles. An independent learning attitude followed by high learning motivation can improve learning outcomes (Hendrawan \& Sirine, 2017).

The properly designed learning videos can improve the quality of students' comprehension. Data analysis shows $50 \%$ of students find it helpful in learning. The explanations in the video are able to accelerate students' comprehension and they are also helped in answering questions in the LKPD (Student Worksheet). As a teacher, you have an important task in presenting interesting and communicative videos so that student learning activities can run well (Nurrohma \& Purnomo 2020). Communicative learning videos encourage the students to be more interactive to participate in learning so that they can lead to maximum learning outcomes (Buchner, 2018; Hadijah, 2016).

\section{Fulfillment of Purpose and Information}

Learning that implement video, it can meet learning objectives if it is well designed and complete. Before the video is created, the ideal step of the teacher is to map the learning objectives to be achieved. It means that the presentation of information or illustrations in the video cannot be separated from the stated objectives. Most of the existing videos do not meet the learning objectives but are more of a theoretical orientation. Meanwhile, learning aims to provide theoretical and practical information so that students' skills can increase (Sani, 2013).

Besides the learning objectives, the teacher pays attention to, the way to convey the information must be communicative so that students can understand. The choice of diction and speed of delivery are important notes in presenting information. Improper or difficult and fast diction can interfere with students understanding the information conveyed by the teacher through learning videos. Data analysis shows that $69.44 \%$ can sometimes understand the information presented and $30.56 \%$ can and some cannot understand the information. Teachers must be careful in managing information and the rhythm of information presentation so that the video provides significant benefits and contributions to improve learning outcomes (Hadijah, 2016). 


\section{Grab Attention}

Display and icon in learning videos can entertain and attract students' attention in learning. Icons or animations can attract the attention of students up to $58.33 \%$. This situation encourages teachers to design models and animations in the video that are not original but provide illustrations that support the presentation of information. On the other hand, the inappropriate animation can have an impact on the perspective for understanding the information (Mustafa, Hermandra, \& Zulhafizh, 2019). It implies that the teacher as the maker and presenter of information can think or make a design before the video is presented to students.

Yunita \& Wijayanti (2017) and Araya, Farsani, \& Hernández (2016) argue that the display of learning video content can attract students' attention to learn. The current analysis data $44.44 \%$ find it interesting with the presentation of learning videos. This emotionally attractive display can direct the perspective of students in learning. As a teacher, you must take this into account in order to motivate students to continue learning so that their learning outcomes can also increase. The existence of good learning motivation helps students in achieving maximum learning outcomes. Thus, various considerations must still be undertaken by the teacher so that the learning videos presented really make a meaningful contribution.

\section{Conclusion}

Analysis of the need for developing learning videos for physics subjects at SMA during the Covid-19 period is an important part that must be undertaken by the teacher to improve the quality of learning. Learning by utilizing video will be meaningful if it meets the learning needs of students. Explaindio-based learning videos provide space for teachers to design videos according to learning needs. The videos presented are still based on learning objectives that can meet theoretical and practical goals by paying attention to the appearance and rules of communicative language. Complete and communicative learning videos can provide meaningful information and experiences to students so that it can bring a positive impact on student learning progress.

\section{Acknowledgement}

I thank all the components who involved in this research. To the supervisors of this research, Dr. Zlirfan, S.Si, M.Si. and Dr. Fakhruddin, M.T., a $12^{\text {th }}$ grade student of SMAN 4 Pekanbaru who voluntarily participated in the success of the research, and also family who always support the implementation of this research. 


\section{References}

Al-Tabany, T. I. B. (2017). Designing Innovative, Progressive, and Contextual Learning Model. Prenada Media.

Araya, R., Farsani, D., \& Hernández, J. (2016). How to Attract Students' Visual Attention. In European Conference on Technology Enhanced Learning (pp. 30-41). Springer, Cham.

Aviana, R., \& Hidayah, F. F. (2015). Pengaruh Tingkat Konsentrasi Belajar Siswa terhadap Daya Pemahaman Materi pada Pembelajaran Kimia di SMA Negeri 2 Batang. Jurnal Pendidikan Sains (JPS), 3(1), 30-33.

Budiyono. (2020). Inovasi Pemanfaatan Teknologi Sebagai Media Pembelajaran di Era Revolusi 4.0. Jurnal Kependidikan: Jurnal Hasil Penelitian dan kajian Kepustakaan dibidang Pendidikan, Pengajaran dan Pembelajaran. 6(2), 300-309.

Buchner, J. (2018). How to Create Educational Videos: from Watching Passively to Learning Actively. $R \& E-S O U R C E, 12,1-10$.

Busyaeri, A., Udin, T., \& Zaenudin, A. (2016). Pengaruh Penggunaan Video Pembelajaran terhadap Peningkatan Hasil Belajar Mapel IPA di MIN Kroya Cirebon. Al Ibtida: Jurnal Pendidikan Guru MI, 3(1), 116-137.

Ekayani, P. (2017). Pentingnya Penggunaan Media Pembelajaran untuk Meningkatkan Prestasi Belajar Siswa. Jurnal Fakultas Ilmu Pendidikan Universitas Pendidikan Ganesha Singaraja, 2(1), 1-11.

Falahudin, I. (2014). Pemanfaatan Media dalam Pembelajaran. Jurnal Lingkar Widyaiswara, 1(4), 104-117.

Hadijah, S. (2016). Teaching by Using Video: Ways to Make it More Meaningful in EFL Classrooms. Proceedings of ISELT FBS Universitas Negeri Padang, 4(2), 307-315.

Hamdanillah, N., Harjono, A., \& Susilawati, S. (2017). Pengaruh Model Pembelajaran Advance Organizer Menggunakan Video Pembelajaran terhadap Hasil Belajar Fisika Peserta Didik Kelas XI. Jurnal Pendidikan Fisika dan Teknologi, 3(2), 119-127.

Hendrawan, J. S., \& Sirine, H. (2017). Pengaruh Sikap Mandiri, Motivasi, Pengetahuan Kewirausahaan terhadap Minat Berwirausaha (Studi Kasus pada Mahasiswa FEB UKSW Konsentrasi Kewirausahaan). Asian Journal of Innovation and Entrepreneurship, 2(03), 291-314.

Ichsan, I. Z., Dewi, A. K., Hermawati, F. M., \& Iriani, E. (2018). Pembelajaran IPA dan Lingkungan: Analisis Kebutuhan Media Pembelajaran pada SD, SMP, SMA di Tambun Selatan, Bekasi. JIPVA (Jurnal Pendidikan IPA Veteran), 2(2), 131-140.

Kadir, S. F. (2014). Keterampilan Mengelola Kelas dan Implementasinya dalam Proses Pembelajaran. Al-Ta'dib, 7(2), 16-36.

Lamba, M. S., Rawat, M. A., Jacob, M. J., Arya, M. M., Rawat, M. J., Chauhan, M. V., \& Panchal, M. S. (2014). Impact of Teaching Time on Attention and Concentration. Age (in Years), 18(22), 23-27.

Melinda, V. A., Degeng, N. S., \& Kuswandi, D. (2018). Pengembangan Media Video Pembelajaran IPS Berbasis Virtual Field Trip (VFT) pada Kelas V SDNU Kratonkencong. JINOTEP (Jurnal Inovasi dan Teknologi 
Pembelajaran): Kajian dan Riset dalam Teknologi Pembelajaran, 3(2), 158-164.

Mustafa, M. N., Hermandra, H., \& Zulhafizh, Z. (2019). Teachers' Strategies to Design Media to Implement Communicative Leaning in Public Schools. Journal of Educational Sciences, 3(1), 13-24.

Mutia, R., Adlim, A., \& Halim, A. (2017). Pengembangan Video Pembelajaran IPA pada Materi Pencemaran dan Kerusakan Lingkungan. Jurnal Pendidikan Sains Indonesia (Indonesian Journal of Science Education), 5(2), 108-114.

Nurrohma, F., \& Purnomo, E. A. (2020). The Effectiveness of Learning Videos to Improve Studentsmathematic Communication Skills. Edusaintek, 4, 47-54

Nurseto, T. (2011). Membuat Media Pembelajaran yang Menarik. Jurnal Ekonomi dan Pendidikan, 8(1), 19-35.

Putri, D.T.N., \& Isnani, G. (2015). Pengaaruh Minat dan Motivasi Terhadap Hasil Belajar Pada Mata Pelajaran Pengantar Administarsi Perkantoran. Jurnal Pendidikan Bisnis \& Manajemen, 1(2), 118-124.

Salmina, M. (2019). Penerapan Model Pembelajaran Discovery Learning pada Materi Dimensi Tiga dengan Bantuan Video Pembelajaran. Numeracy Journal, 6(2), 247-254.

Sani, R. A. (2013). Inovasi Pembelajaran. Jakarta: Bumi Aksara.

Syaparuddin, S., Meldianus, M., \& Elihami, E. (2020). Strategi Pembelajaran Aktif dalam Meningkatkan Motivasi Belajar PKn Peserta Didik. Mahaguru: Jurnal Pendidikan Guru Sekolah Dasar, 1(1), 30-41.

Tafonao, T. (2018). Peranan Media Pembelajaran dalam Meningkatkan Minat Belajar Mahasiswa. Jurnal Komunikasi Pendidikan, 2(2), 103-114.

Yunita, D., \& Wijayanti, A. (2017). Pengaruh Media Video Pembelajaran terhadap Hasil Belajar IPA Ditinjau dari Keaktifan Siswa. Sosiohumaniora: Jurnal Ilmiah Ilmu Sosial dan Humaniora, 3(2), 153160.

Zulhafizh \& Permatasari, S. (2020). Developing Quality of Learning in the Pandemic Covid-19 Through Creative and Critical Thinking Attitudes. Jurnal Pajar (Pendidikan dan Pengajaran), 4(5), 937-949.

Zulhafizh, Z. (2020a). Membina Aktivitas Belajar Mahasiswa di Perguruan Tinggi Melalui Metode TIE (Translation, Interpretation, Extrapolation) pada Masa Pandemi Covid-19. Jurnal Kependidikan: Jurnal Hasil Penelitian dan Kajian Kepustakaan di Bidang Pendidikan, Pengajaran dan Pembelajaran, 6(3), 502-511.

How to cite this article:

Nurliana, Zulirfan, \& Fakhruddin. (2021). Need Analysis for the Development of Learning Video Based on Explaindio in Physics Lesson of Senior High School to Improve Learning Outcomes During the Covid-19 Pandemic. Journal of Educational Sciences, 5(3), 491-501. 